\title{
Pengaruh Literasi Keuangan Terhadap Perilaku Konsumtif Generasi Milenial Di Kota Bandung
}

\begin{abstract}
Consumptive behavior is actions taken to fulfill various types of human needs. If consumption is carried out excessively and not just based on needs, then it is not a reasonable consumption anymore, but it has become a consumptive behavior. Millennials are considered as the most consumptive generation, especially online shopping and prioritizing short-term needs rather than long-term needs. Theoretically consumptive behavior is influenced by low financial literacy. This research was conducted in the millennial generation in Bandung, which in 2019 was 19-38 years old. The sample used in this study was calculated using Slovin formula so that there were at least 400 respondents. Technique used in this research is nonprobability sampling with a purposive sampling approach. The data analysis technique used is descriptive analysis and simple linear regression analysis. The results of this study concluded that financial literacy had a significant negative effect on the consumptive behavior of millennial generation in the city of Bandung. With the level of financial literacy and consumptive behavior included in the medium category.
\end{abstract}

\begin{abstract}
ABSTRAK: Kegiatan konsumsi merupakan tindakan yang dilakukan untuk memenuhi berbagai jenis kebutuhan manusia. Apabila konsumsi dilakukan secara berlebihan dan bukan menurut kebutuhan saja, maka perilaku itu sudah bukan konsumsi yang wajar melainkan menjadi perilaku konsumtif. Generasi milenial dinilai sebagai generasi yang paling konsumtif terutama dalam belanja online dan lebih memproritaskan kebutuhan jangka pendek daripada kebutuhan jangka panjang. Secara teoritis perilaku konsumtif dipengaruhi oleh literasi keuangan yang rendah. Penelitian ini dilakukan pada generasi milenial di Kota Bandung yang pada 2019 berusia 19-38 tahun. Sampel dalam penelitian ini dihitung dengan menggunakan rumus Slovin sehingga diperoleh responden minimal sebanyak 400 orang. Pengambilan sampel menggunakan teknik nonprobability sampling dengan pendekatan purposive sampling. Teknik analisis data yang digunakan adalah analisis deskriptif dan analisis regresi linear sederhana. Hasil penelitian ini menyimpulkan bahwa literasi keuangan berpengaruh signifikan negatif terhadap perilaku konsumtif generasi milenial di Kota Bandung. Dengan tingkat literasi keuangan dan perilaku konsumtif yang termasuk ke dalam kategori sedang.
\end{abstract}

\section{Zahra Qurotaa'yun', Astrie} Krisnawati $^{2}$

Fakultas Ekonomi \& Bisnis, Universitas Telkom

J1. Telekomunikasi No.1, Kota

Bandung, Indonesia

Keywords: Financial Literacy, Consumptive Behavior, Millennial Generation.
Kata Kunci: literasi keuangan, perilaku konsumtif, generasi milenial. 


\section{Pendahuluan}

Nielsen Global Survey of Consumer Confidence and Spending Intentions, mengemukakan bahwa Indonesia termasuk sebagai 3 negara teratas yang paling optimis memiliki tingkat kepercayaan konsumen dan insentisitas keinginan belanja tertinggi di dunia (nielsen.com, 2016). Kusumaningtuti S. Soetiono selaku anggota dewan komisioner Otoritas Jasa Keuangan (OJK) mengatakan jika masyarakat Indonesia memiliki uang, mereka akan lebih mengutamakan belanja atau konsumsi dibanding menabung (ekonomi.kompas.com, 2015)

Adapun Generasi Milenial yang dikenal sebagai pembelanja online terbesar di Indonesia (republika.co.id, 2017). Berdasarkan hasil riset yang dilakukan oleh Snapcart, berdasarkan usia, setengah atau $50 \%$ pembelanja online merupakan Generasi Milenial (berusia antara 25-34 tahun) (marketeers.com, 2018). Hal ini disebabkan karena adanya mobilitas tinggi dan serba terkoneksi dengan internet yang membuat dampak pada lifestyle dan kebiasaan generasi milenial tidak bisa dipisahkan dari kemudahan mereka untuk berbelanja online (kompas.com, 2018). Generasi ini bahkan melibatkan teknologi dalam segala aspek kehidupannya mulai dari keperluan transportasi, membeli makanan, jalan-jalan, berbelanja pakaian hingga membeli kebutuhan sehari-hari (republika.co.id, 2017). Dari beberapa kategori usia generasi milenial, generasi milenial yang paling konsumtif adalah first jobbers, yakni orang-orang yang saat ini berusia di awal 20-an dan baru memiliki pekerjaan (cnnindonesia.com, 2018). Hal ini disebabkan karena mereka baru memiliki pendapatan sendiri, dan masih bisa menggunakan seluruh pendapatan tersebut untuk dirinya sendiri.

Riset pelopor mesin pencari belanja (shopping search engine) dan platform pembanding harga, Priceza, menyatakan terdapat lima kota besar di
Indonesia yang menjadi sumber utama pembelanja online terbanyak di Indonesia, yang terdiri dari Jakarta, Surabaya, Medan, Bandung, dan Makassar (marketeers.com, 2018). Dari kelima kota dengan pembelanja online terbanyak di Indonesia terdapat Kota Bandung yang merupakan kota dengan tingkat konsumsi masyarakat tertinggi di Indonesia pada Oktober 2015 (economy.okezone.com, 2015).

Salah satu faktor yang diduga dapat menyebabkan munculnya perilaku konsumtif adalah kurangnya literasi keuangan (Tenriawaru et al., 2018). Perilaku konsumtif menurut Lina dan Rosyid (1997) dalam Pratiwi dan Yani (2016) terdiri atas 3 dimensi yaitu yaitu pembelian impulsif, pemborosan dan mencari kesenangan. Sedangkan Menurut Program for International Student Assessment (2012) dimensi yang terdapat pada literasi keuangan terdiri atas uang dan transaksi, perencanaan dan pengelolaan keuangan, risiko dan keuntungan serta financial landscape dimana kemampuan empat dimensi tersebut menjadi aspek penilaian untuk mengetahui kemampuan individu dalam merencanakan dan mengelola keuangan untuk masa depan (Dikria dan Mintarti, 2016).

Pemahaman akan literasi keuangan dirasa penting apalagi bagi generasi milenial yang dikenal cenderung konsumtif dan tidak memiliki manajemen keuangan yang baik (beritasatu.com, 2017). Bahkan pada 2020 mendatang, generasi ini diprediksi akan menjadi tulang punggung perekenomian Indonesia karena berkurangnya generasi Baby Boomer dan Generasi X (Ali \& Purwandi, 2016:13). Oleh sebab itu, sebaiknya generasi milenial melengkapi diri dengan proteksi asuransi dan investasi sebagai modal dalam membangun masa depan (ekonomi.kompas.com, 2018). Adapun masalah finansial yang akan dihadapi generasi millennial pada 5-10 tahun ke depan diantaranya yaitu pengeluaran lebih 
besar dari pendapatan, pinjaman yang bertambah, dan tidak dapat memiliki tempat tinggal karena pendapatan dan biaya cicilan rumah yang tidak seimbang (beritasatu.com, 2017).

\section{Pengembangan Hipotesis}

Pengaruh Literasi Keuangan Terhadap Perilaku Konsumtif

PISA (2012) mendefinisikan literasi keuangan sebagai pengetahuan dan pemahaman atas konsep dan risiko keuangan, berikut keahlian, motivasi, serta keyakinan diri untuk menerapkan pengetahuan dan pemahaman tersebut untuk membuat keputusan yang efektif, meningkatkan kesejahteraan keuangan individu dan masyarakat, serta memungkinkan berpartisipasi dalam kehidupan ekonomi.

Imawati et al. (2013) menjelaskan bahwa perilaku konsumtif merupakan suatu perilaku membeli di mana individu mengkonsumsi barang dan jasa secara berlebihan, yang tidak lagi didasarkan atas pertimbangan rasional serta lebih mementingkan faktor keinginan daripada kebutuhan yang hanya untuk mencapai kepuasan maksimal dan kesenangan saja sehingga menimbulkan pemborosan.

Penelitian terdahulu yang dilakukan oleh Imawati et al. (2013) menyatakan bahwa literasi keuangan berpengaruh negatif dan signifikan terhadap perilaku konsumtif yang membuktikan bahwa semakin tinggi literasi keuangan seseorang maka semakin rendah pula perilaku konsumtif yang dimiliki. Imawati juga mengatakan literasi keuangan melatih manusia mengontrol perilaku konsumtifnya sehingga dapat membuat skala prioritas dalam berbelanja, dan kecil kemungkinan membeli barang yang kurang bermanfaat maupun boros. Hal ini didukung dengan hasil penelitian dari Harli et al. (2015), Dikria dan Mintarti (2016) dan Fattah et al. (2018) yang mengemukakan bahwa literasi keuangan memiliki pengaruh negatif dan signifikan terhadap perilaku konsumtif. Adapun berdasarkan penjelasan yang telah dikemukakan di atas maka hipotesis yang akan dibuktikan kebenarannya yaitu "Literasi keuangan berpengaruh signifikan negatif terhadap perilaku konsumtif generasi milenial di Kota Bandung"

\section{Metode, Data dan Analisis}

Metode penelitian yang digunakan dalam penelitian ini adalah metode kuantitatif. Penelitian ini dilakukan pada generasi milenial di Kota Bandung yang pada tahun 2019 berusia 19-38 tahun. Sampel penelitian dihitung dengan menggunakan rumus Slovin sehingga diperoleh responden minimal sebanyak 400 orang. Pengambilan sampel menggunakan teknik nonprobability sampling dengan pendekatan purposive sampling. Teknik analisis data yang digunakan adalah analisis deskriptif dan analisis regresi linear sederhana.

\section{Hasil dan Diskusi}

Hasil Uji Asumsi Klasik

1. Uji Normalitas

Uji normalitas digunakan untuk menguji apakah nilai residual yang dihasilkan dari regresi terdistribusi secara normal atau tidak dimana model regresi yang baik adalah yang memiliki nilai residual yang terdistribusi secara normal. Adapun pengujian normalitas pada penelitian ini menggunakan metode Kolmogorov Smirnov dengan bantuan software IBM SPSS versi 23 dengan hasil sebagai berikut: 
Tabel 1. Hasil Uji Normalitas

One-Sample Kolmogorov-Smirnov Test

\begin{tabular}{|c|c|c|}
\hline & & $\begin{array}{l}\text { Unstandardiz } \\
\text { ed Residual }\end{array}$ \\
\hline $\mathrm{N}$ & & 400 \\
\hline \multirow[t]{2}{*}{ Normal Parameters ${ }^{a, b}$} & Mean & .0000000 \\
\hline & Std. Deviation & 7.56517298 \\
\hline \multirow[t]{3}{*}{ Most Extreme Differences } & Absolute & .035 \\
\hline & Positive & .035 \\
\hline & Negative & -.028 \\
\hline \multicolumn{2}{|l|}{ Test Statistic } & .035 \\
\hline \multicolumn{2}{|l|}{ Asymp. Sig. (2-tailed) } & $200^{\mathrm{c} . \mathrm{d}}$ \\
\hline \multicolumn{3}{|c|}{ a. Test distribution is Normal. } \\
\hline \multicolumn{3}{|l|}{ b. Calculated from data. } \\
\hline \multicolumn{3}{|c|}{ c. Lilliefors Significance Correction. } \\
\hline
\end{tabular}

Priyatno (2017:90) mengatakan apabila hasil uji menunjukkan signifikansi lebih dari 0,05 maka kesimpulannya data berdistribusi normal. Berdasarkan tabel 1 . diketahui bahwa nilai Asymp. Sig. (2tailed) sebesar 0,200>0,05 maka data dinyatakan lolos uji normalitas karena nilai residual tersebut normal.

\section{Uji Heteroskedastisitas}

Uji heteroskedastisitas memiliki tujuan untuk menguji apakah dalam model regresi terjadi ketidaksamaan variabel dari residual satu pengamatan ke pengamatan lain. Dalam penelitian ini, uji heteroskedastisitas dapat dilihat dengan menggunakan uji glejser dengan bantuan software IBM SPSS versi 23 dengan hasil sebagai berikut:

Tabel 2. Hasil Uji Heteroskedastisitas coefficients $^{\mathrm{a}}$

\begin{tabular}{|c|c|c|c|c|c|c|}
\hline \multirow[b]{2}{*}{ Model } & & \multicolumn{2}{|c|}{ Unstandardized Coefficients } & \multirow{2}{*}{$\begin{array}{c}\text { Standardized } \\
\text { Coefficients } \\
\text { Beta }\end{array}$} & \multirow[b]{2}{*}{ t } & \multirow[b]{2}{*}{ Sig. } \\
\hline & & $B$ & Std. Error & & & \\
\hline 1 & (Constant) & 8.357 & 1.272 & & 6.572 & .000 \\
\hline & Literasi Keuangan & -.038 & .020 & -.092 & -1.850 & .065 \\
\hline
\end{tabular}

Berdasarkan tabel di atas dapat dilihat bahwa nilai signifikansi pada uji heteroskedastisitas adalah 0,065. Sesuai dengan pendapat dari Priyanto (2017:126) apabila nilai signifikansi > 0,05 maka tidak terjadi masalah heteroskedastisitas. Hasil output di atas memperlihatkan nilai signifikansi sebesar 0,065 >0,05 sehingga dapat disimpulkan tidak terjadi masalah heteroskedastisitas pada model regresi.
Hasil Regresi Linier Sederhana

Analisis Regresi sederhana digunakan untuk mengetahui pengaruh atau hubungan antara variabel independen yaitu literasi keuangan terhadap variabel dependen yaitu perilaku konsumtif yang dilakukan pada 400 responden dari generasi milenial di Kota Bandung. Adapun analisis persamaan regresi linier sederhana pada penelitian ini menggunakan bantuan software IBM SPSS versi 23 dengan hasil sebagai berikut:

Tabel 3. Hasil Persamaan Regresi Linier Sederhana

Coefficients $^{a}$

\begin{tabular}{|c|c|c|c|c|c|c|}
\hline \multirow[b]{2}{*}{ Model } & & \multicolumn{2}{|c|}{ Unstandardized Coefficients } & \multirow{2}{*}{$\begin{array}{c}\begin{array}{c}\text { Standardized } \\
\text { Coefficients }\end{array} \\
\text { Beta }\end{array}$} & \multirow[b]{2}{*}{$t$} & \multirow[b]{2}{*}{ Sig. } \\
\hline & & B & Std. Error & & & \\
\hline 1 & (Constant) & 71.352 & 2.127 & & 33.550 & .000 \\
\hline & Literasi Keuangan & -.487 & .034 & -.581 & -14.230 & .000 \\
\hline
\end{tabular}

Dari tabel 3. di atas diperoleh model persamaan regresi linier sederhana sebagai berikut:

$$
\mathrm{Y}=71,352-0,487 \mathrm{X}
$$

Persamaan regresi yang didapat adalah $\mathrm{Y}=71,352-0,487 \mathrm{X}$ dimana $\mathrm{Y}$ adalah perilaku konsumtif dan $\mathrm{X}$ adalah literasi keuangan. Nilai konstanta (a) adalah 71,352 yang dapat diartikan jika literasi keuangan nilainya adalah 0 , maka perilaku konsumtif generasi milenial di Kota Bandung bernilai 71,352. Nilai koefisien regresi (b) bernilai negatif yaitu $-0,487$, ini dapat diartikan bahwa setiap peningkatan literasi keuangan sebesar satu satuan, maka perilaku konsumtif akan menurun sebesar 0,487. Koefisien regresi tersebut bernilai negatif yang menandakan variabel literasi keuangan memberikan pengaruh berlawanan terhadap perilaku konsumtif sehingga semakin tinggi literasi keuangan yang dimiliki maka perilaku konsumtif akan semakin menurun, dan begitu pula sebaliknya.

\section{Hasil Uji Hipotesis (Uji T)}

Pengujian hipotesis dengan uji $\mathrm{T}$ memiliki fungsi sebagai alat untuk 
mengetahui apakah variabel independen berpengaruh secara signifikan atau tidak terhadap variabel dependen (Priyatno, 2017:163). Dalam uji hipotesis, penulis menggunakan uji $\mathrm{T}$ untuk mengetahui pengaruh antara literasi keuangan terhadap perilaku konsumtif dengan hipotesis penelitian sebagai berikut:

Ho : Tidak terdapat pengaruh signifikan negatif antara literasi keuangan terhadap perilaku konsumtif generasi milenial di Kota Bandung.

Ha : Terdapat pengaruh signifikan negatif antara literasi keuangan terhadap perilaku konsumtif generasi milenial di Kota Bandung.

Adapun hasil pengujian hipotesis yang telah diolah oleh penulis dengan menggunakan bantuan software IBM SPSS versi 23 adalah sebagai berikut:

Tabel 4. Hasil Pengujian Hipotesis

Coefficients $^{\mathrm{a}}$

\begin{tabular}{|c|c|c|c|c|c|c|}
\hline \multirow[b]{2}{*}{ Model } & & \multicolumn{2}{|c|}{ Unstandardized Coefficients } & \multirow{2}{*}{$\begin{array}{c}\begin{array}{c}\text { Standardized } \\
\text { Coefficients }\end{array} \\
\text { Beta } \\
\end{array}$} & \multirow[b]{2}{*}{$t$} & \multirow[b]{2}{*}{ Sig. } \\
\hline & & $B$ & Std. Error & & & \\
\hline 1 & (Constant) & 71.352 & 2.127 & & 33.550 & .000 \\
\hline & Literasi Keuangan & -.487 & .034 & .581 & -14.230 & .000 \\
\hline
\end{tabular}

Berdasarkan tabel 4. di atas dapat diketahui bahwa -t hitung memiliki nilai sebesar -14,230 dengan nilai signifikansi sebesar 0,000. Karena nilai -t hitung $14,230<-$ t tabel -1,966 dan nilai signifikasi $0,000<0,05$, maka Ho ditolak dan Ha diterima. Jadi dapat disimpulkan bahwa literasi keuangan memiliki pengaruh signifikan dan negatif terhadap perilaku konsumtif. Nilai t hitung bernilai negatif menandakan bahwa apabila literasi keuangan semakin meningkat maka perilaku konsumtif akan semakin menurun, dan begitu pula sebaliknya.

Koefisien Determinasi

Koefisien determinasi $\left(\mathrm{R}^{2}\right)$ digunakan untuk mengetahui seberapa besar kontribusi variabel independen (X) yaitu literasi keuangan terhadap variabel dependen (Y) yaitu perilaku konsumtif. Adapun hasil perhitungan koefisien determinasi $\left(\mathrm{R}^{2}\right)$ dengan menggunakan software IBM SPSS versi 23 dapat dilihat pada tabel berikut:

Tabel 5. Hasil Koefisien Determinasi

Model Summary

\begin{tabular}{l|l|c|c|r|}
\hline Model & $\mathrm{R}$ & R Square & $\begin{array}{c}\text { Adjusted R } \\
\text { Square }\end{array}$ & $\begin{array}{c}\text { Std. Error of } \\
\text { the Estimate }\end{array}$ \\
\hline 1 & $.581^{\mathrm{a}}$ & .337 & .336 & 7.57467 \\
\hline
\end{tabular}

Tabel 5. di atas menunjukkan bahwa literasi keuangan memiliki pengaruh sebesar 33,7\% terhadap perilaku konsumtif, sedangkan sisanya yaitu $66,3 \%$ dipengaruhi oleh faktor lain selain literasi keuangan yang tidak diteliti dalam penelitian ini.

\section{Kesimpulan, Keterbatasan dan Saran Kesimpulan}

Berdasarkan hasil penelitian yang telah dilakukan mengenai pengaruh literasi keuangan terhadap perilaku konsumtif generasi milenial di Kota Bandung, maka diperoleh hasil kesimpulan yaitu sebagai berikut:

1. Literasi keuangan generasi milenial di Kota Bandung memiliki nilai sebesar $67,9 \%$ yang termasuk ke dalam kategori sedang.

2. Perilaku konsumtif generasi milenial di Kota Bandung memiliki nilai sebesar $60,9 \%$ yang termasuk ke dalam kategori sedang.

3. Literasi keuangan memiliki pengaruh yang signifikan negatif terhadap perilaku konsumtif generasi milenial di Kota Bandung dimana jika literasi keuangan naik maka perilaku konsumtif akan menurun. Besarnya pengaruh literasi keuangan terahadap perilaku konsumtif generasi milenial di Kota Bandung yaitu sebesar 33,7\%, sedangkan $66,3 \%$ lagi dipengaruhi 
oleh variabel lain yang tidak diteliti pada penelitian ini.

Keterbatasan

Keterbatasan dalam penelitian ini adalah:

a. Dalam penelitian ini faktor-faktor yang mempengaruhi perilaku konsumtif hanya menggunakan satu variabel independen, yaitu literasi keuangan. Sedangkan masih banyak faktor lain yang mempengaruhi perilaku konsumtif.

b. Objek penelitian hanya meneliti generasi milenial di Kota Bandung.

Saran

1. Saran bagi Penelitian Selanjutnya

a. Penelitian ini hanya menggunakan satu variabel bebas yaitu literasi keuangan. Untuk penelitian selanjutnya dianjurkan menambah variabel bebas selain literasi keuangan. Terdapat 66,3\% variabel lain yang dapat mempengaruhi perilaku konsumtif, variabel ini bisa seperti faktor demografis, gaya hidup, pengendalian diri, lingkungan keluarga, teman sebaya (peer group), dan variabel lainnya.

b. Objek penelitian juga dapat dikembangkan tidak hanya pada generasi milenial di Kota Bandung tetapi dapat dilakukan pada generasi milenial di kota-kota lain seperti Jakarta, Surabaya, Medan, Makassar dan kota lainnya. Penelitian selanjutnya juga dapat meneliti generasi lain misalnya generasi baby boomer, generasi $\mathrm{X}$ dan generasi $\mathrm{Z}$.

2. Saran bagi Generasi Milenial di Kota Bandung

a. Generasi milenial dapat mengontrol perilaku berbelanja dengan cara mengedepankan kebutuhan daripada keinginan. Misalnya dengan membuat ataupun merancang daftar belanja agar lebih fokus membeli barang yang lebih diprioritaskan/dibutuhkan serta berkomitmen untuk mematuhi daftar belanja/budget yang telah disusun.

b. Generasi milenial dapat meningkatkan literasi keuangannya terutama pada dimensi risiko dan keuntungan dengan cara mencari informasi di berbagai media sosial seperti jejaring sosial, website, aplikasi dan lain sebagainya yang sudah terdaftar dan diawasi oleh Otoritas Jasa Keuangan. Selain itu milenial juga dapat meningkatkan pengetahuannya melalui buku.

c. Generasi milenial dianjurkan mulai menyisihkan pendapatannnya sedini mungkin dengan cara menabung atau berinvestasi secara rutin. Langkah awal yang tepat bagi generasi milenial adalah dengan melakukan reksadana online.

3. Saran bagi Pemerintah dan Lembaga Keuangan

a. Meningkatkan edukasi mengenai literasi keuangan khususnya dimensi risiko dan keuntungan melalui berbagai media sosial seperti jejaring sosial, website, aplikasi, buku dan lain sebagainya atau mengembangkan program yang sudah ada seperti program "SIKAPI Uang dengan Bijak" yang diluncurkan oleh Otoritas Jasa Keuangan (OJK) yang lebih dikhususkan bagi generasi milenial.

b. Pemerintah yang diwakili oleh OJK dapat bekerjasama dengan sekolah, perguruan tinggi, kantor maupun komunitas yang ada di Kota Bandung untuk melakukan edukasi dengan cara mengadakan seminar, event, forum maupun pelatihan mengenai cara mengontrol dan menyeimbangkan keuangan sehari- 
hari, merencanakan keuangan jangka panjang serta mengelola berbagai produk keuangan seperti menabung dan berinvestasi guna mewujudkan kesejahteraan keuangan di masa depan.

\section{DAFTAR PUSTAKA}

Ali, H., \& Purwandi, L. (2016). INDONESIA 2020: The Urban Middle-Class Millennials. Jakarta: Alvara Research Center.

Agustin, D. (2017, Januari 31). Mengapa Generasi Millennials Suka Belanja. Retrieved from https://republika.co.id/berita/gayahidup/trend/17/01/31/okn5b2328mengapa-generasi-millennialssuka-belanja [Diakses 5 Januari 2019]

Badan Pusat Statistik. (2017, Agustus 24). Jumlah Penduduk Menurut Kelompok Umur dan Jenis Kelamin di Kota Bandung 2017. Retrieved from

https://bandungkota.bps.go.id/static table/2019/01/04/179/proyeksipenduduk-menurut-kelompokumur-dan-jenis-kelamin-di-kotabandung-2017.html [Diakses 22 Juli 2019]

Bachar, S. (2018, Juni 26). Lima Kota Indonesia dengan Jumlah Pembelanja Online Terbesar. Retrieved from http://marketeers.com/lima-kotaindonesia-dengan-jumlahpembelanja-online-terbesar/ [Diakses 20 Desember 2018]

Bachdar, S. (2018, Maret 24). Generasi Milenial Masih Pembelanja Online Terbesar di Indonesia. Retrieved from https://marketeers.com/generasi- milenial-masih-pembelanja-onlineterbesar-di-indonesia/ [Diakses 10 Juni 2019]

Fattah, F. A. , Indriayu, M., \& Sunarto. (2016). Pengaruh Literasi Keuangan dan Pengendalian Diri terhadap Perilaku Konsumtif Siswa SMA Muhammadiyah 1 Karanganyar. Jurnal Pendidikan Bisnis dan Ekonomi, 4(1), 11-21.

Harli, F. C., Linawati, N., \& Memarista, G. (2015). Pengaruh Financial Literacy dan Faktor Sosiodemografi Terhadap Perilaku Konsumtif. Jurnal Finesta, 3(1), 58-62.

Imawati, I., Susilaningsih, \& Ivada, E. (2013). Pengaruh Financial Literacy terhadap Perilaku Konsumtif Remaja pada Program IPS SMA Negeri 1 Surakarta Tahun Ajaran 2012/2013. Jurnal Pendidikan Ekonomi Universitas Sebelas Maret, 2(1), 48-58.

Jannah, K. M. (2015, Desember 09). Konsumsi Masyarakat Bandung Paling Tinggi, Jakarta Justru Terendah. Retrieved from https://economy.okezone.com/read/ 2015/12/09/320/1263788/konsumsi -masyarakat-bandung-palingtinggi-jakarta-justru-terendah [Diakses 22 Oktober 2018].

Jatmiko, B. P. (2015, Agustus 8). OJK: Orang Indonesia Makin Konsumtif. Retrieved from https://ekonomi.kompas.com/read/ 2015/08/08/110746226/OJK.Orang .Indonesia.Makin.Konsumtif [Diakses 26 Oktober 2019]

Lubis, M. (2016, Februari 3). INDONESIA KEMBALI BERADA PADA PERINGKAT KETIGA NEGARA PALING OPTIMISTIS DI DUNIA. 
Retrieved from http://www.nielsen.com/id/en/press -room/2016/Indonesia-KembaliBerada-Pada-Peringkat-KetigaNegara-Paling-Optimistis-DiDunia.html [Diakses 26 Oktober 2018]

OECD. (2012). PISA 2012: Financial Literacy Assesment Framework. OECD Publishing.

Pratiwi, I. W., \& Yani, R. E. (2016). Hubungan Konformitas dengan Perilaku Konsumtif pada Remaja.
Jurnal Psikologi Pendidikan dan Pengembangan, 4(1), 11-21.

Priyatno, D. (2017). Panduan Praktis Olah data Menggunakan SPSS. Yogyakarta: ANDI.

Tenriawaru, A., Wicaksono, B., \& Saniatuzzulfa, R. (2018). Hubungan antara Kecenderungan Kepribadian Narsistik dan Financial Literacy dengan Perilaku Konsumtif pada Mahasiswa. Jurnal Wacana Psikologi, 10(2), 1-13. 